\title{
In and Around the Balkans: Romance Languages and the Making of Layered Languages
}

\author{
Francesco Gardani \\ Professor of Romance Linguistics, Institute of Romance Studies, Faculty of \\ Arts and Social Sciences, University of Zurich, Zurich, Switzerland \\ francesco.gardani@uzh.ch
}

\author{
Michele Loporcaro \\ Full Professor of Romance Linguistics, Institute of Romance Studies, Faculty \\ of Arts and Social Sciences, University of Zurich, Zurich, Switzerland \\ loporcar@rom.uzh.ch
}

\begin{abstract}
Alberto Giudici
Assistant in Romance Linguistics, Institute of Romance Studies, Faculty of Arts and Social Sciences, University of Zurich, Zurich, Switzerland alberto.giudici@uzh.ch
\end{abstract}

\begin{abstract}
The languages of the Balkans are a rich source of data on contact-induced language change. The result of a centuries long process of lexical and structural convergence has been referred to as a 'sprachbund'. While widely applied, this notion has, however, increasingly been questioned with respect to its usefulness. Addressing the linguistic makeup of the Balkan languages, the notion of sprachbund is critically assessed. It is shown that a) the Balkan languages and the Balkan linguistic exclaves (Albanian and Greek spoken on the Italian peninsula) share similar contact-induced phenomena, and b) the principal processes underlying the development of the Balkan languages are borrowing and reanalysis, two fundamental and general mechanisms of language change.
\end{abstract}

\section{Keywords}

Balkan sprachbund - borrowing - layered languages - linguistic area - reanalysis Romance languages - structural convergence 
The languages of the Balkans - principally including the Indo-European (sub)branches of Albanian, Greek, (South) Slavic and (Eastern) Romance - are a gold mine when it comes to instances of contact-induced language change; they are a paramount example of linguistic and socio-cultural processes which over the centuries have led to high levels of lexical and structural convergence. As is well known, the result of this process of convergence has been referred to as a 'sprachbund', a term, coined by Trubetzkoy (1923) (see Section 2.2), that both has been present in the literature for approximately one hundred years and has been applied to a number of cases of linguistic convergence cross-linguistically (Campbell, 2017: 20-22). However, the notion of sprachbund (also known as 'linguistic area' and 'convergence area') has increasingly been questioned with respect to its usefulness.

The present paper introduces a special issue of the Journal of Language Contact focusing on Romance languages as they participate in the making of layered languages in the Balkans; the scope of this issue, however, extends beyond the geographic boundaries of the Balkans as it includes Albanian and Greek linguistic exclaves on the Italian peninsula, in contact with ItaloRomance varieties, as well as the Greek dialects Heptanesian, Pontic, Aivaliot and Cypriot in contact with Turkish and varieties of Romance. ${ }^{1}$ In this introductory paper, we shall address the linguistic makeup of the Balkan languages, focusing on the characteristics that led linguists to develop the idea of linguistic area, and summarize critical claims by Dahl (2001), Stolz (2002), Campbell (2006; 2017), among others, on the notion of sprachbund. More specifically, we will show that a) the Balkan languages and the Balkan linguistic exclaves share similar contact-induced phenomena; and b) the principal processes underlying the development of the Balkan languages are borrowing and reanalysis, two fundamental and general mechanisms of language change.

The paper is organized as follows: Section 2 sketches the linguistic makeup of the Balkans (Section 2.1) and provides a critical assessment of the notion of sprachbund (Section 2.2). Section 3 discusses the occurrence of the same phenomena generally considered key properties of the Balkan languages, outside the Balkans. Section 4 summarizes the seven contributions to the special issue.

1 Into the bargain, the (northern) geographic boundary itself of the Balkan has been a matter of unrelenting debate (cf., e.g., Reed, Kryštufek and Eastwood, 2004: 9-10; Vezenkov, 2017: 116-119). 
The Balkan peninsula (Fig. 1) is the land mass bounded by the Black Sea to the east, by the Sea of Marmara, the Aegean, Mediterranean, Ionian Seas to the south, by the Adriatic Sea to the west and by the rivers Danube and Sava to the north (but see fn. 1). Here, four distinct subgroups and several varieties of the Indo-European language family coexist: (i) Albanian, (ii) Greek, (iii) the South Slavic languages Bulgarian, Macedonian, and some dialects of the Bosnian-Croatian-Montenegrin-Serbian complex, (iv) the Eastern Romance languages Romanian, Istro-Romanian (spoken in Istria), ${ }^{2}$ Megleno-Romanian (spoken in a small area in northern Greece and the Republic of North Macedonia) and Aromanian (spoken in northern and central Greece, southern Albania, the Republic of North Macedonia and south-western Bulgaria) (for Eastern Romance, cf. Maiden, 2016). Some authors such as Friedman and Joseph (2017:55) count in also the co-territorial dialects of (Indic) Romani and to some extent the co-territorial dialects of Ibero-Romance Judezmo (spoken in Saloniki and Istanbul) and of Turkic (especially West Rumelian Turkish and Gagauz, both belonging to the Oghuz subbranch). In the following subsections, we shall outline the linguistic makeup of the Balkans (Section 2.1) and summarize the vivid debate sparkling around the notion of sprachbund, in particular as it relates to the Balkan languages (Section 2.2).

\subsection{Linguistic Makeup}

Starting from the early nineteenth century, scholars observed the spread of grammatical features across the Balkans: besides implicit thoughts by Leake (1814: 380), the first linguistic works explicitly concerned with the diffusion of grammatical structures in the Balkans are Kopitar (1829: 86), Miklosich (1861), Schuchardt (1884), Seliščev (1925) and, crucially, Sandfeld (1902) and Sandfeld (1926). ${ }^{3}$ The property which attracted the interest of linguists the most was a high degree of structural convergence, as it is perhaps best exemplified by the following statement by Kopitar (1829: 86): "nur eine Sprachform herrscht, aber mit dreyerley Sprachmaterie [there is one grammar with three lexical materials, our translation]." While Kopitar's statement is blatantly exaggerated and should rather be taken as a slogan, instances of structural parallelism

2 Note that Istro-Romanian is generally not included in the alleged 'Balkan sprachbund'; alternatively, some authors consider it the least Balkan of the four Daco-Romance languages and claim that it shares a little amount of Balkanisms with the core Balkan languages (Zegrean, 2012: 43).

3 The 1926 paper, written in Danish, is better known as Sandfeld (1930) in French. 


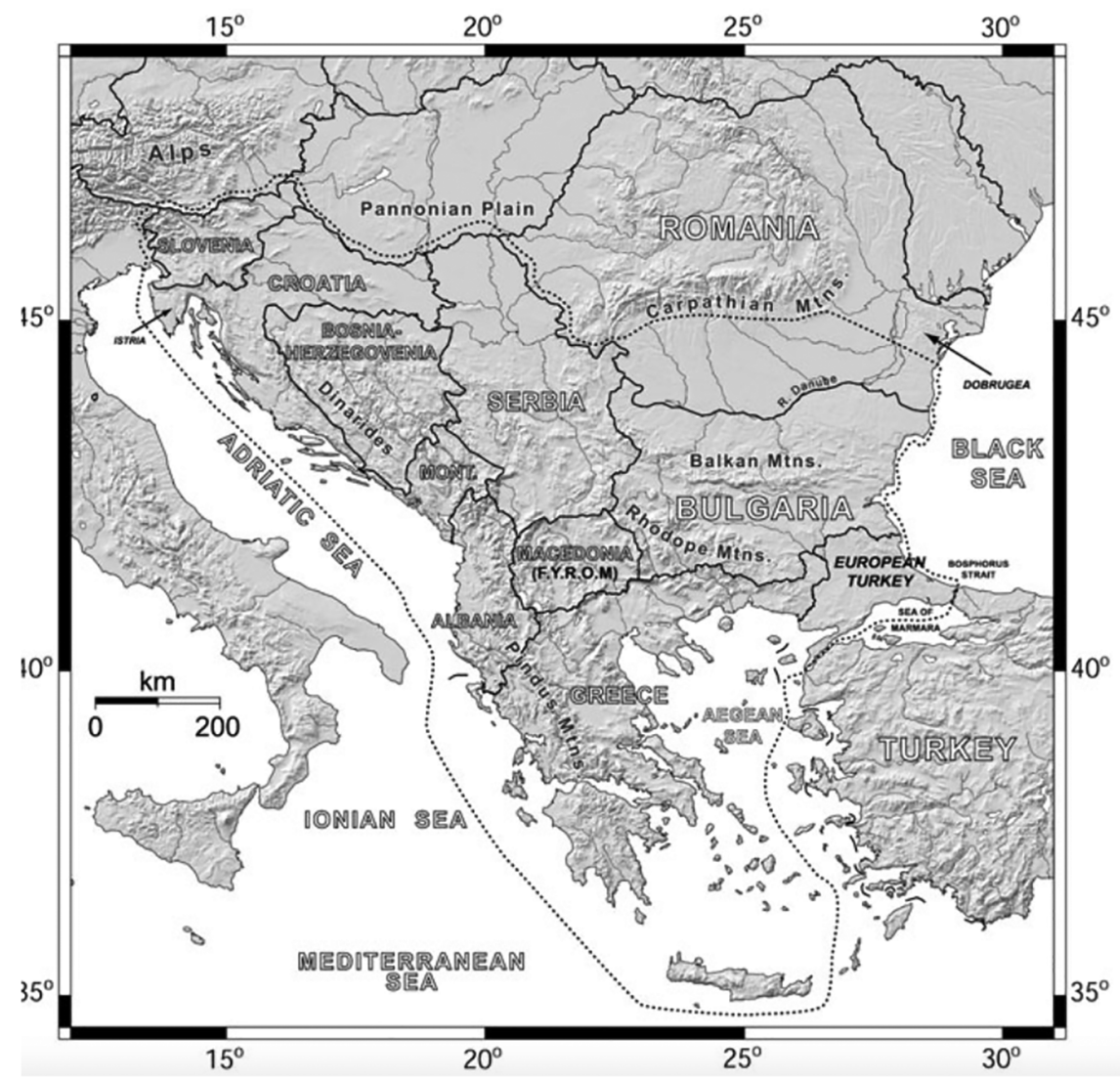

FIGURE 1 Map showing the major political boundaries, topography and rivers of the Balkan Peninsula (source: Reed, Kryštufek, and Eastwood, 2004: 10; reprinted by permission from Springer Nature Customer Service Centre GmbH)

are indeed observable. A case in point is the 'verbal complex', a string of material ordered in a template-like fashion including markers for negation, tense, modality, argument structure and a verb, as exemplified by the data in (1), adapted from Friedman and Joseph $(2017: 56) .{ }^{4}$

4 Convergence of this kind, however, should be considered as surface similarity. As Sims and Joseph (2019: 101) have shown, "the internal structuring of the Balkan verbal complex differs from one language to another". Also Friedman (2011: 279), with respect to the feature of object doubling, speaks of the "differences in conditioning factors, which in turn indicate different degrees of integration into the grammar". 


\begin{tabular}{|c|c|c|c|c|c|c|}
\hline a. Albanian & $s^{\prime}$ & do & te & ja & & jep \\
\hline & NEG & FUT & SBJV & 3.SG.DAT/3.SG.ACC & & give.1.SG \\
\hline b. Daco- & $n u$ & $o$ & $s \breve{a}$ & $\hat{\imath}$ & & dau \\
\hline Romanian & NEG & FUT & SBJV & 3.SG.DAT/3.SG.ACC & & give.1.SG \\
\hline c. dialectal & $\delta e$ & $\vartheta e$ & $n a$ & $t u$ & to & 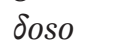 \\
\hline Greek & NEG & FUT & SBJV & 3.SG.GEN & 3.SG.ACC & give.1.SG \\
\hline d. dialectal & ne & ke & $d a$ & $m u$ & go & davam \\
\hline Macedonian & NEG & FUT & SBJV & 3.SG.DAT & 3.SG.ACC & give.1.SG \\
\hline e. Serbian & пес́u & & $d a$ & $m u$ & $g a$ & dam \\
\hline & NEG.I & T.1.SG & SBJV & 3.SG.DAT & 3.SG.ACC & give.1.SG \\
\hline
\end{tabular}

Miklosich (1861) was the first scholar to identify a series of features common to the Balkan languages, although the number of features to be included in the Balkan sprachbund, often called 'Balkanisms') (cf. Sandfeld, 1930; Joseph, 1983; 1992; 2010; Friedman and Joseph, 2017; 2022) varies consistently among authors and has led to a distinction between primary (or 'core') and secondary (or 'peripheric') Balkan languages. Here is a tentative list (including, whenever available, Romance examples).

a. presence of a (stressed) mid-to-high central vowel in Albanian, Romanian, Bulgarian, some dialects of Macedonian and Serbian, some Romani varieties, and Turkish;

$b$. presence of $i-e-a-o-u$ in the vowel inventory without phonological contrasts in quantity, openness, or nasalization in Greek, Tosk Albanian, Romanian, Macedonian, Bulgarian, some dialects of Serbian, and Romani;

c. devoicing of word-final stops in Bulgarian, Macedonian, MeglenoRomanian, Modern Greek, some Romani dialects, South Montenegrin and Torlak Serbian, and Turkish;

d. voicing of voiceless stops after nasals (NT > ND) in Albanian, Greek, Aromanian;

$e$. presence of the voiced/voiceless interdental spirants $\delta \vartheta(\gamma)$ in Aromanian, Albanian, Greek, (dialectal) Macedonian;

$f$. presence of a future tense built with a reduced, often invariant, form of the verb 'want' in Greek, Tosk Albanian, Daco-Romanian, Istro-Romanian, Aromanian (2), Macedonian, Bulgarian, Serbian, and Romani; 
(2) Aromanian (Capidan, 1932: 466)

va s-dormu

FUT SUBJ-sleep.1.SG

'I will sleep'

g. morphologically realized distinction of witnessed vs reported (including admirative and dubitative) in Albanian, Bulgarian, Macedonian, and Turkish, ${ }^{5}$ and to a lesser extent in Romani, Serbian, and Aromanian (3);

(3) (Gorna Belica Frasheriote) Aromanian (Friedman, 1994)

$\begin{array}{llll}\text { Abe, munduem } \quad k a & \text { Silja } & \text { kăntac-ka! } \\ \text { hey I.thought that } & \text { Silja } & \text { sing.PART-ADMV }\end{array}$

'Hey, I thought Silja is singing!'

h. reduction in the nominal case system, especially a falling together of genitive and dative cases in Greek, Albanian, Daco-Romanian (4a-b), Istro-Romanian, Megleno-Romanian, Aromanian, Bulgarian, and Macedonian;

Daco-Romanian (adapted from Tomić, 2006: 132)

(4)
a. Petru
$i=a$
dat
Petru
3.SG.DAT=has given
'Petru has given a flower to the girl.'
b. floarea fetei
flower.DEF.F.SG girl.DEF.F.SG.OBL
'the girl's flower'

fetei

o floare

girl.F.SG.OBL INDEF flower

i. enclitic definite article in Albanian, Daco-Romanian, ${ }^{6}$ Istro-Romanian, Megleno-Romanian (5), Aromanian, Macedonian, Bulgarian, and south-eastern (Torlak) Serbian;

(5) Megleno-Romanian (Capidan, 1925: 149)

casi-li

house.PL-DEF

'the houses'

5 The most likely source of the evidentiality distinction in the Balkans is Turkish (cf. Section 2.2), where reported information (also referred to as 'non-firsthand' and 'indirective') on past events is encoded by the suffix -mIş, yielding, e.g., gelmiş 'obviously came' vs unmarked geldi 'came' (cf. Johanson, 2000: 81).

6 For Romanian, Ledgeway (2017) has convincingly shown that the definite article is no longer enclitic but inflectional. 
j. analytic comparative for adjectives in Greek, Albanian, Daco-Romanian, Istro-Romanian (6), Megleno-Romanian, Aromanian as well as Romani and Turkish; ${ }^{7}$

(6) Istro-Romanian (Kovačec, 1971: 108)

mài bùr

more good

'better'

k. object clitic doubling in Albanian, Greek, Daco-Romanian (7), MeglenoRomanian, Aromanian, Bulgarian, and Macedonian, dialectally in Serbian, and to a limited extent in Romani;

l. personal direct objects introduced by a preposition in Daco-Romanian (7), some Aromanian dialects (Sobolev, 2008: 117), and in southern Macedonian dialects;

(7) Daco-Romanian

$\begin{array}{llll}\text { l-am } & \text { văzut } & p e /^{*}(p e) & \text { Ana } \\ \text { овJ-have } & \text { seen } & \text { to } & \text { Ana }\end{array}$

'I saw/have seen Ana.'

$m$. double determination in deixis, that is, the co-occurrence of a demonstrative adjective with a definite article and a noun in Greek (8) and in Albanian and Slavic varieties;

$\begin{array}{llll}\text { Greek } & & & \\ \text { Idha } & \text { afton } & \text { ton } & \text { andhra } \\ \text { saw.1.SG } & \text { this } & \text { DEF } & \text { man }\end{array}$

'I saw this man.'

$n$. use of enclitic oblique pronouns as possessive markers in Greek, Slavic, Daco-Romanian, Istro-Romanian, Megleno-Romanian, Aromanian (9);

(9) Aromanian (Capidan, 1932: 415)

sora $=t s i$

sister=POSS.2.SG

'your sister'

7 Bulgarian and Macedonian are generally included in the group of languages sharing the use of an analytically build comparative (cf., e.g., Joseph, 2010: 622). However, both languages use prefixation, e.g., Bulgarian slab 'weak', poslab 'weaker'. 
$o$. decreased use of a non-finite verbal complement replaced by finite complement clauses in Greek, Macedonian, Bulgarian, Serbian (especially the Torlak dialects), Romani and also occurring in Albanian (especially Tosk) and Eastern Romance (10);

\begin{tabular}{lll}
\multicolumn{2}{l}{ Daco-Romanian (Tomić, 2006) } & \\
Evită $\quad$ să $\quad$ te & vadă \\
avoid.3.SG SUBJ 2.SG & see.3.SG.PRs.SUBJ \\
'(S)he avoids seeing you.' &
\end{tabular}

The occurrence of the features listed in $a-o$ (and of some others) in (some of) the Balkan languages led linguists to elaborate the notion of sprachbund, i.e., a group of languages whose similarity is not due to (narrow) genealogic relatedness, that is, inheritance from a common ancestor language, but to "historical development" (Boas, 1929: 7), that is, mutual influences over time. In the following section we introduce the notion of sprachbund, especially as it relates to the Balkans.

\subsection{Contact-Induced Change in the Balkans}

According to a recent definition, a sprachbund is "a geographically delimited area including languages from two or more language families (or subgroups) which share significant traits. Most of these traits are not found in languages from the same families outside the area, and can be considered area-defining" (Aikhenvald, 2018: 149). This definition evidently echoes the first explicit proposal of the concept of sprachbund that Trubetzkoy had formulated 95 years earlier:

besides such genetic grouping, languages which are geographical neighbors also often group independently of their origin. It happens that several languages in a region defined in terms of geography and cultural history acquire features of a particular congruence, irrespective of whether this congruence is determined by common origin or only by a prolonged proximity in time and parallel development. We propose the term language union [jazykoryj sojuz] ${ }^{8}$ for such groups which are not based on the genetic principle (Trubetzkoy, 1923: 116, quoted from Toman, 1995: 204).

8 The term sprachbund appears for the first time in Trubetzkoy's 'Proposition 16': "Groups composed of languages which show a high degree of similarity with respect to syntax, a similarity in the principles of morphological construction, and which offer a large number of common culture words, sometimes also an outward similarity in the phonological 
A comparison of the two definitions shows that the intension of sprachbund has stayed unchanged for decades in its core elements, viz. structural convergence and geographic contiguity. However, an intense debate has sparked concerning some defining criteria of sprachbund, such as, for example, the minimum number of shared grammatical features, oscillating between a single trait (e.g., Jakobson, 1931) and several ones (Thomason, 2001: 101), and the minimum number of languages to which the trait(s) extend(s), e.g., at least three according to Schaller (1975: 58) (see Campbell, 2006: 7-10; 2017, for excellent overviews). As a result of such divergent opinions, the number of definitions of sprachbund "is almost coextensive with the number of linguists working in the field of areal linguistics" (Stolz, 2006: 33). Also the key criterium of geographic contiguity (Boas, 1929: 6) has met with general criticism (cf. Stolz, 2006: 36). The assumption, implicit in the topography-based approach, that geographic proximity is a proxy for linguistic contact has been argued to be inadequate and regarded as "post hoc attempts to impose geographical order on varied conglomerations of these borrowings" (Campbell, 2006: 1). Another property which some linguists have considered specific to sprachbünde is multilateral diffusion, as opposed to unilateral diffusion such as that occurring in substratum interference. For example, Tosco (2000: 359) weighs the existence of an Ethiopian linguistic area and concludes that it is not tenable on the basis of the fact that " $[n]$ o multilateral contact is observable, but only unilateral diffusion in the form of a shared substratum". While seemingly promising, this property, too, is not conclusive: as Aikhenvald and Dixon (2001: 11) put it, "depending on the historical events, the direction of diffusion can suddenly change [...]; this creates a 'historically' multilateral area, every synchronic 'cut' of which can be considered unilateral."

Finally, a central question in the sprachbund debate is that asked by Dahl concerning the "reality" of a linguistic area: "In the end, we are led to the following more far-going question about the notion of area: to what extent do areas $[\ldots]$ have a reality of their own and to what extent are they just convenient ways of summarizing certain phenomena?" (Dahl, 2001: 1458). Admittedly, the question concerning the reality of linguistic areas is hard to answer, and we

inventories, -but which possess neither systematic sound correspondences, nor ha[ve] any correspondences in the phonological makeup of the morphological units nor any common basic lexical items- such languages groups we call Sprachbünde" (Trubetzkoy, 1928: 17-18, translated by Campbell, 2006: 3). 
cannot answer it here. For all the reasons surveyed thus far, first and foremost the non-specificity of structural convergence to linguistic areas, some prominent scholars (in particular, Dahl, 2001; Campbell, 2006; 2017; Stolz, 2006) have seriously questioned the validity of the notion, concluding that "[a]n area is then simply the sum of many such binary ["one language influences another"] relationships" (Dahl, 2001: 1458) and that "linguistic areas boil down merely to a study of local linguistic borrowing and its history, and little else" (Campbell, 2006: 2$) \cdot{ }^{9}$

Whether one believes or not in sprachbund, in the end, it is unquestionable that the Balkan languages display a high degree of structural convergence. The Balkan languages that share the most Balkan features are Albanian, Macedonian, Bulgarian, and Romanian (Schaller, 1975: 100). As far as Romance is concerned, according to this approach, Aromanian, Megleno-Romanian, and Romanian are Balkan languages stricto sensu, whereas extinct Dalmatian (Bartoli, 1906; Maiden, 2020), Istro-Romanian (see Loporcaro et al., 2021), and Judezmo (see Friedman and Joseph, 2021a) are languages of the Balkans, that is, languages which are spoken within the geographic boundaries of the Balkans.

Structural convergence is a frequent outcome of borrowing as the principal mechanism of contact-induced language change (Gardani, forthc.). In the case of the Balkans, the source of borrowing is known in some cases: for example, the loan verb marker - $(i) s^{-}(12)$ is ultimately Greek and the evidentiality distinction (cf. feature $g$ ) was most likely borrowed from Turkish (Friedman, 1999: 521). Often, however, the exact origin of a spread Balkan trait is hard to trace $^{10}$ and, even when we do not know it, it appears likely that the structural parallelisms found in the Balkan languages have resulted from a stratification of several processes of change (both contact-induced and internal), throughout a turbulent history characterized by socio-political circumstances leading to complex population movements and, during some periods, to ethnic and linguistic intermingling (Banfi, 1991; Calic, 2019). Consequently, the source of borrowing is not necessarily a single dominant language (Lindstedt, 2014). During the Middle Ages, the languages of power in the Balkans were-at various times-Greek, Slavic, and Latin/Romance (especially Balkan Latin, i.e., the Latin variety used in the territory of Roman Dalmatia (cf. Skok, 1915) and

9 Still other scholars focusing on socio-historical aspects of language contact claim that the notion of sprachbund "remains a useful heuristic referring to the results of historical and social processes of language contact" (Friedman, 2011: 275).

10 For a discussion on the issue of determining directionality of change, exemplified with the diffusion of object doubling, see Friedman (2011: 283). 
Venetian); during the Ottoman Empire, Turkish dominated the Balkan peninsula as the language of administration, trade, and the military; for centuries Church Slavonic was the language used in religious service in Bulgaria, Macedonia, Wallachia and Moldavia, while Greek enjoyed prestige among Christians as the language of the Greek Orthodox church; in particular, Greek was the language of the culture in the Balkans, and also a language of trade (cf. Friedman, 2006: 669-670). However, Greek is less Balkanized a language than Balkan Slavic, Eastern Romance, and Albanian (Lindstedt, 2014) and its influence was particularly strong in the southern Balkan regions, south of the so-called Jireček line (Jireček, 19o1: 13-14), separating the influence of Greek from that of Latin, to the north). Besides borrowing, at least two more general mechanisms are responsible for spread of features and convergence, namely reanalysis and contact-induced grammaticalization, that is, a grammaticalization process which is transferred from a source language to a recipient language (Heine, 1994; Heine and Kuteva, 2003; 2005; Gast and van der Auwera, 2012). A combination of borrowing and reanalysis is evident in the diffusion of the formative - $(i) s^{-}$, originally borrowed from Greek where it forms the perfective. As Breu (1991a; 1991b) has convincingly demonstrated, this formative has become the general loan verb integration suffix throughout the Balkan languages." ${ }^{11}$ For example, given the Modern Greek verb agapo 'to love', -s- marks the perfective as it attaches to the perfective stem agapi-, yielding, e.g., the past form agápisa. Through the contact with other languages in the Balkans, this formative has been reanalyzed and refunctionalized as a loan verb marker (Gardani, 2016). Thus, in Arvanítika, a variety of Tosk Albanian spoken in Greece that has been involved in a four centuries lasting contact with Greek (Tsitsipis, 1998: 1), Greek agapo has been integrated as agapís 'I love'. The ensuing generalization of the borrowed formative as a loan verb marker, in terms of what Breu (1991a: 42) calls analogische Ausweitung des Entlehnungsverfahrens, is shown by the fact that the formative also applies to Greek verbs that do not display the sigmatic perfective stem. For example, in (11a) and (11b), the formative -s- occurs on a Greek-origin deponent verb sképtomai / skéftomai 'to think, reflect'. In Greek, deponent and medio-passive verbs are asigmatic, thus, the perfective stem of sképtomai / skéftomai is skept- / skeft- (data from Haebler, 1965: 166).

11 It is curious that this widespread trait has never been counted in as a Balkan sprachbund feature in any well-known feature list. 
(11)

Arvanítika (Albanian)

a.

fcep-s-em

think-LVM-PRS.1.SG

'I think'

b.
Greek

sképtome

skéfthika

MEDP-think-LVM-PST.1.SG

'I thought'

Similarly, in Bulgarian, verbs borrowed from Turkish are integrated by adding -(i)s- to the Turkish preterit morpheme -DI- (realized as - $d \iota,-d i,-d u,-d \ddot{u}$, $-t \iota,-t i,-t u,-t \ddot{u})$, which itself serves as a loan verb marker. The form bojadisvam in (12a) is made up of the Turkish boyadı (12b), preterit of boyamak, to which a loan verb marker and the inflectional formative are suffixed (data from Breu, 1997: 159).

$\begin{array}{ll}\text { a. } & \text { Bulgarian } \\ & \text { bojad-is-vam } \\ & \text { paint-LVM-1.SG } \\ & \text { 'I paint' }\end{array}$
b. Turkish boya-dı paint-PST.PFV 's/he painted'

\section{3} Balkan Languages Outside the Balkans

Beyond the Balkans, contact between Romance languages and other non-Romance Balkan languages has occurred in three main Balkan exclaves in the south of Italy. These involve the contact of Italo-Romance with Slavic (cf., e.g., Breu, 1998), Albanian (cf., e.g., Altimari and Savoia, 1994), and Greek (cf., e.g., Höhn et al., 2017), respectively.

As is well known (Rohlfs, 1937; 1977), the coexistence and linguistic contact between Italo-Romance speakers and Greek speakers (viz. Greko/Grecanico in Calabria and Griko in Salento) have led over the centuries to a considerable amount of grammatical convergence. In these areas, the result of contact has often manifested itself in processes of reanalysis of existing Romance features and patterns to adjust to the Greek model (Ledgeway, 2013; Ledgeway et al., 2018). Such convergence phenomena include, for example, case (dative and genitive), the use of determiners, verb movement and complementation (finite vs infinitival) (on the recession of the infinitive as a syntactic category, see Rohlfs, 1958; Loporcaro, 1995; 2013: 155-156;). For example, southern Calabrian (exemplified with Sinopolese in (13a)) shows a convergence towards the syntax of Griko (13b) as it allows finite complement clauses such as in (13a) 
on the model of Italo-Greek (13b), while the expected Italo-Romance feature would be infinitival complementation (13c) (data from Rohlfs, 1972: 320, 327).
a. Sinopolese (Reggio
Vogghiu
$m i$
dormu.
b. Griko (Castrignano
want.PRS.1.SG IRR
sleep.PRS.1.SG
etèlo na
want.PRS.1.SG IRR
c. Italian
Voglio
dormire.
plòso.
sleep.PRS.1.SG
want.PRS.1.SG sleep.INF
'I want to sleep.'

It is noteworthy that finite complementation under subject co-reference is one of the features considered key to the Balkan sprachbund as it occurs in Greek, Macedonian, Bulgarian, Serbian (especially the Torlak dialects), Romani, Albanian (especially Tosk), Daco-Romanian, Aromanian and Eastern Romance (cf. feature $o$ and (10) in Section 2.1). Just as in the case of the Balkan languages, for example Romanian (Maiden, 2016: 121-122), in Sinopolese, too, we observe a tendency towards an increased use of finite complement clauses. In both southern Calabrian and Greko, infinitival complementation has been maintained, often alongside competing finite $\mathrm{mi}$ / na clauses, in conjunction with a class of restructuring predicates such as, e.g., the modal verb potiri 'can' in Mosorrofa Calabrese (14) (data from Loporcaro, 1995: 342) and kùo 'hear' in Greko (15) (data from Ledgeway, 2013; cf. also Baldissera, 2013; 2015 for Griko). ${ }^{2}$

(14) southern Calabrese (Mosorrofa)

$\begin{array}{lll}\text { non } & \text { pozzu } & \text { caminari } \\ \text { NEG } & \text { can.1.SG } & \text { walk }\end{array}$

'I can't walk.'

(15) Greko

Egò tus= àcua $\quad$ platèttsi / na platèttsusi.
I them= hear.PST.1.SG talk.INF / that talk.SBJV.3.PL
'I heard them talking.'

12 With respect to Griko, Baldissera (2015: 278) observes that properties, such as the retention of the infinitive, which is not shared by Standard Modern Greek, "can be found in Medieval Greek and can be explained as a result of reinforcement of the conservative tendency by contact with the neighboring Romance varieties." 
Another key 'Balkan' feature, the falling together of genitive and dative cases (cf. feature $h$. in Section 2.1), has a parallel in Palizzese. Again as the result of the contact between Italo-Romance and Italo-Greek, we find a genitive structure that apparently calques the Greek dative-genitive syncretism; in reality, it is rather "a hybrid structure in which the indirect object is referenced in part through dative marking on the verbal head $[n c i]$ and in part through genitive

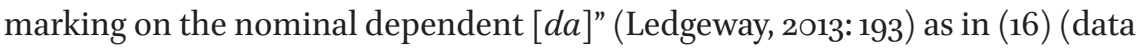
from Squillaci, 2017: 6-7).

\begin{tabular}{|c|c|c|c|c|c|c|}
\hline a. Palizze & $\begin{array}{l}\text { e } n c i=d e s i \\
\text { to.her=give.PST.1.SG }\end{array}$ & $\begin{array}{l}u \\
\mathrm{DEF}\end{array}$ & $\begin{array}{l}\text { regalu } \\
\text { gift }\end{array}$ & $\begin{array}{l}d a \\
\text { DEF.GEN }\end{array}$ & $\begin{array}{l}\text { figghiola. } \\
\text { virl }\end{array}$ & \\
\hline b. Greko & $\begin{array}{l}\text { tis }=e d o k a \\
\text { toher=oive.PST. } 1 \text { SG }\end{array}$ & & & $\begin{array}{l}\text { kaloma } \\
\text { gift }\end{array}$ & $t i$ & $\begin{array}{l}\text { miccedda. } \\
\text { girl }\end{array}$ \\
\hline c. Italian & $\begin{array}{l}\text { ho } \\
\text { I.have }\end{array}$ & $\begin{array}{l}\text { dato } \\
\text { given }\end{array}$ & $\begin{array}{l}i l \\
\mathrm{DEF}\end{array}$ & $\begin{array}{l}\text { regalo } \\
\text { gift }\end{array}$ & $\begin{array}{l}\text { alla } \\
\text { to.DEF }\end{array}$ & $\begin{array}{l}\text { bambina. } \\
\text { girl }\end{array}$ \\
\hline
\end{tabular}

Still another key Balkan feature, the diffusion of analytically realized comparatives from originally synthetic structures (feature $j$ in Section 2.1), is paralleled by the change occurred in Molise Croatian (17a) under the influence of Romance (17b) (Breu, 1996: 26; 2009), as opposed to synthetic comparative formation in Standard Croatian (17c).

\begin{tabular}{lll} 
a. & \multicolumn{2}{l}{ Molise } \\
veče & lip \\
more & pretty \\
'prettier' &
\end{tabular}

$\begin{array}{lll}\text { b. } & \text { Italian } & \\ & \text { più } & \text { bello } \\ & \text { more } & \text { pretty } \\ & \text { 'prettier' } & \end{array}$

c. Croatian

ljepši

pretty.COMP

'prettier'

The data thus presented and the case studies by Breu (this special issue), Ledgeway, Schifano and Silvestri (this special issue), and Ralli (this special issue) show that the encounter between Romance and Balkan non-Romance languages outside the geographic boundaries of the Balkans has given rise to the same types of change as those originated in the Balkan sprachbund.

Summing up, we have shown that the languages outside the geographic boundaries of the Balkans, viz. Greek varieties, Albanian, and Croatian, in contact with Italo-Romance, have undergone the same types of change as the sprachbund languages themselves. Both groups can be characterized in terms of Aikhenvald's (2006: 5) metaphor of 'layered' languages, that is, languages whose "inherited 'core' is discernible underneath the subsequent 'layers' of innovative influence from outside". While it is obvious that all languages are mixed to some extent, Aikhenvald stresses that the significance of this layering varies. In the specific case of the Balkan languages, the degree of "diffusional 
cumulation" (Swadesh, 1951) is so extraordinary that these languages display several layers of lexical material and grammatical features as a result of multiple processes of change and "mutual reinforcement" (Lindstedt, 2000), including borrowing, contact-induced grammaticalization, and secondary reanalysis-driven processes of contact-induced change, due to largely pairwise contact over long stretches of time.

This special issue of the Journal of Language Contact is opened by a 'caveat paper'. In Establishing contact. Slavonic influence on Romanian morphology, Martin Maiden warns the (contact) linguists that they must fully exploit the full range of available comparative evidence in order to be able to exclude the possibility that apparently contact-induced effects are, in fact, explicable by internal factors. Maiden shows that the influence of Slavic models attributed to certain paradigmatic patterns of root allomorphy in the Romanian verbal system is at best indemonstrable. He makes this case by deconstructing claims that certain aspects of the distribution of root allomorphy in verb inflectional paradigms were induced by contact with Bulgarian. A more economical explanation - he argues - is achieved if Romanian is not singled out in a pairwise comparison with Bulgarian but rather duly analyzed against the background of what is independently known on (this aspect of) the Romance verb system (cf. Maiden, 2018).

The following paper, Convergence by shared ancestry in Romance by Paul Widmer, Stefan Dedio and Barbara Sonnenhauser, is also a methodological paper. Because in many cases of apparent contact-induced change the relevance of shared ancestry in the language sample and its interaction with processes such as matter and pattern borrowing (Gardani 2020a, 2020b) are difficult to specify, the authors quantify the change in similarity since the late Middle Ages in a sample of Romance and Germanic languages, with data from a selected grammatical domain, viz. the expression of reflexivity, and crucially compare their dynamics with patterns of change of similarity occurring in two contact areas, the British Isles and the Balkans. The results indicate a maintenance and gain of similarity in Romance as opposed to a loss of similarity in Germanic.

In Contact-induced complexification in the gender system of Istro-Romanian, Michele Loporcaro, Francesco Gardani and Alberto Giudici provide the first in-depth description of the borrowing of Croatian collective numerals into the northern branch of Istro-Romanian. They show that the introduction of a few lexical items encoding quantification has precipitated changes in the 
recipient language, in a way that led to a restructuring of the morphosyntactic system, introducing (sub)gender overdifferentiation on just two agreement targets and, thereby, a complexification in this area of the grammar of northern Istro-Romanian whose degree of complexity had already increased previously, in two rounds, via the borrowing from Slavic of neuter agreement markers.

In Eastern and Western Romance in the Balkans - The contrasting but revealing positions of the Danubian Romance languages and Judezmo, Victor Friedman and Brian Joseph compare and contrast two Romance languages, Aromanian and Judeo-Spanish, and examine the extent to which they show the effects of Balkan-specific language contact. To this end, they review the behavior of the "usual suspects" in the two languages, including all the traits listed in a-o (Section 2.1), plus a series of properties of the sound patterns of the two languages as well as the occurrence of what Friedman and Joseph (2014; 2020) have termed "ERIC loans" (= "Essentially Rooted In Conversation"). They conclude that while Aromanian is thoroughly 'Balkan' as to its structure and lexicon, Judeo-Spanish is much less so (the latter finding converging with the results in Widmer, Dedio and Sonnenhauser) and argue that the difference between the languages as to their degree of linguistic Balkanization is due to several factors, including chronology, social circumstances, and the structure of the language at the time it entered the Balkans.

The next three papers are dedicated to Balkan exclaves. In Italo-Albanian: Balkan inheritance and Romance influence, Walter Breu deals with contact-induced change in Italo-Albanian and its effects on the Balkan inheritance of this minority language, focusing on the TAM systems, causative construction, and periphrastic structures. He shows that many traditional Balkan features have been weakened or lost in Italo-Albanian, whereas others have even expanded, but always in the direction of Romance models.

In The negative imperative in Southern Calabria. Spirito greco, materia romanza again?, Adam Ledgeway, Norma Schifano and Giuseppina Silvestri investigate imperative morphology in the two extreme southern Italian dialects of Mosorrofa, Cardeto and Gallicianò (Calabria). Capitalizing on new fieldwork data, they show that the differences in the extension of the -ri ending in the negative imperative correlates with differences in the duration of contact with Greko, as this was lost considerably earlier in Mosorrofa and Cardeto than in Gallicianò.

In Contrasting Romance and Turkish as donor languages: Evidence from borrowing verbs in Modern Greek Dialects, Angela Ralli studies loan verb accommodation techniques in a language contact situation involving Greek as recipient and Romance and Turkish as source languages. By drawing evidence from the 
spontaneous speech of speakers of several Greek varieties, she shows that typological (in)compatibility between the source (semi-analytical Romance, agglutinative Turkish) and the recipient (fusional Greek) plays a major role in the process of loan verb integration.

\section{Acknowledgements}

The Swiss National Science Foundation (SNF Grant No. CRSII1_16o739), the University Research Priority Program "Language and Space", and the Institute of Romance Studies of the University of Zurich are gratefully acknowledged for funding the workshop "Romance languages and the others: the Balkan Sprachbund" held at the University of Zurich on May 24-25, 2018.

\section{Abbreviations}

The abbreviations used in this paper are based on Lehmann (2004) and the Leipzig Glossing Rules (available at https://www.eva.mpg.de/lingua/resources/ glossing-rules.php). In addition, admirative is abbreviated as ADMV.

\section{References}

Aikhenvald, Alexandra Y. 2006. Grammars in contact. A cross-linguistic perspective. In Alexandra Y. Aikhenvald and Robert M. W. Dixon (eds.), Grammars in Contact: A Cross-Linguistic Typology, 1-66. Oxford: Oxford University Press.

Aikhenvald, Alexandra Y. 2018. Evidentiality and language contact. In Alexandra Y. Aikhenvald (ed.), The Oxford Handbook of Evidentiality, 148-172. Oxford: Oxford University Press.

Aikhenvald, Alexandra Y. and Robert M. W. Dixon. 20o1. Introduction. In Alexandra Y. Aikhenvald and Robert M. W. Dixon (eds.), Areal Diffusion and Genetic Inheritance: Problems in Comparative Linguistics, 1-26. Oxford: Oxford University Press.

Altimari, Francesco and Leonardo M. Savoia (eds.). 1994. I dialetti italo-albanesi: Studi linguistici storico-culturali sulle comunità arbëreshe. Rome: Bulzoni.

Baldissera, Valeria. 2013. Il dialetto grico del Salento: Elementi balcanici e contatto linguistico. Venice: Università Ca' Foscari Venezia. PhD dissertation.

Baldissera, Valeria. 2015. The Griko dialect of Salento: Balkan features and linguistic contact (Ca' Foscari University of Venice, 2013). Journal of Greek Linguistics 15(2): 271-279. 
Banfi, Emanuele. 1991. Storia linguistica del sud-est europeo: Crisi della Romània balcanica tra alto e basso medioevo. Milan: Angeli.

Bartoli, Matteo. 1906. Das Dalmatische. Altromanische Sprachreste von Veglia bis Ragusa und ihre Stellung in der apennino-balkanischen Romania. Vienna: Hölder.

Boas, Franz. 1929. Classification of American Indian languages. Language 5(1): 1-7.

Breu, Walter. 1991a. Abweichungen vom phonetischen Prinzip bei der Integration von Lehnwörtern. In Klaus Hartenstein and Helmut Jachnow (eds.), Slavistische Linguistik 1990: Referate des XVI. Konstanzer Slavistischen Arbeitstreffens Bochum/ Löllinghausen 19-21.9.1990, 36-69. Munich: Sagner.

Breu, Walter. 1991b. System und Analogie bei der Integration von Lehnwörtern: Versuch einer Klassifikation. Incontri Linguistici 14(1): 13-28.

Breu, Walter. 1996. Überlegungen zu einer Klassifikation des grammatischen Wandels im Sprachkontakt (am Beispiel slavischer Kontaktfälle). Sprachtypologie und Universalienforschung (STUF) 49: 21-38.

Breu, Walter. 1997. Integrazione di prestiti e problemi della fonologia diacronica dell'albanese. In Francesco Altimari (ed.), Atti del $2^{\circ}$ Seminario Internazionale di Studi Albanesi, Rende - San Giacomo di Cerzeto - San Cosmo Alb., 8-1o giugno 1994, 155-168. Rome: Herder.

Breu, Walter. 1998. Romanisches Adstrat im Moliseslavischen. Die Welt der Slaven 43(1): 339-354.

Breu, Walter. 20o9. La comparazione nello slavomolisano. Un risultato tipico del contatto linguistico assoluto. In Carlo Consani, Carmela Perta, Francesca Guazzelli, and Paola Desideri (eds.), Alloglossie e comunità allog lotte nell'Italia contemporanea: Teorie, applicazioni e descrizioni, prospettive; atti del XLI congresso internazionale di studi della Società di Linguistica Italiana (SLI); Pescara, 27 - 29 settembre 2007, 9-39. Rome: Bulzoni.

Calic, Marie-Janine. 2019. The Great Cauldron: A History of Southeastern Europe. Cambridge, Mass.: Harvard University Press.

Campbell, Lyle. 20o6. Areal linguistics: A closer scrutiny. In Yaron Matras, April McMahon and Nigel Vincent (eds.), Linguistic Areas: Convergence in Historical and Typological Perspective, 1-31. New York: Palgrave Macmillan.

Campbell, Lyle. 2017. Why is it so hard to define a linguistic area? In Raymond Hickey (ed.), The Cambridge Handbook of Areal Linguistics, 19-39. Cambridge: Cambridge University Press.

Capidan, Theodor. 1925. Meglenoromânii. I, Istoria şi graiul lor. Bucharest: Cultura Naţională.

Capidan, Theodor. 1932. Aromânii, dialectul Aromân: Studiu lingvistic. Bucharest: Monitorul Oficial și Imprimeriile Statului, Imprimeria Națională.

Dahl, Östen. 2001. Principles of areal typology. In Martin Haspelmath, Ekkehard König, Wulf Oesterreicher, and Wolfgang Raible (eds.), Language Typology and Language Universals, volume 2, 1456-1470. Berlin: De Gruyter. 
Friedman, Victor A. 1994. Surprise! Surprise! Arumanian has had an admirative! Indiana Slavic Studies 7: 79-89.

Friedman, Victor A. 1999. Evidentiality in the Balkan languages. In Uwe Hinrichs (ed.), Handbuch der Südosteuropa-Linguistik, 519-544. Wiesbaden: Harrassowitz.

Friedman, Victor A. 2006. Balkans as a linguistic area. In Keith Brown (ed.), Encyclopedia of Language and Linguistics, 2nd edn., 657-672. Oxford: Elsevier.

Friedman, Victor A. 2011. The Balkan languages and Balkan linguistics. Annual Review of Anthropology 40(1): 275-291.

Friedman, Victor A. and Brian D. Joseph. 2014. Lessons from Judezmo about the Balkan Sprachbund and contact linguistics. International Journal of the Sociology of Language 226: 3-23.

Friedman, Victor A. and Brian D. Joseph. 2017. Reassessing Sprachbunds: A view from the Balkans. In Raymond Hickey (ed.), The Cambridge Handbook of Areal Linguistics, 55-87. Cambridge: Cambridge University Press.

Friedman, Victor A. and Brian D. Joseph. 2021a. Eastern and Western Romance in the Balkans: The contrasting but revealing positions of the Danubian Romance languages and Judezmo. Journal of Language Contact 14(1):127-146.

Friedman, Victor A. and Brian D. Joseph. 2022. The Balkan Languages. Cambridge: Cambridge University Press.

Gardani, Francesco. 2016. Allogenous exaptation. In Muriel Norde and Freek Van de Velde (eds.), Exaptation and Language Change, 227-26o. Amsterdam: Benjamins.

Gardani, Francesco (ed.). 2020a. Borrowing matter and pattern in morphology. Special issue. Morphology $30(4)$.

Gardani, Francesco. 2020b. Borrowing matter and pattern in morphology. An overview. Morphology 30(4): 263-282. doi: 10.1007/s11525-020-09371-5

Gardani, Francesco. forthc. Contact and borrowing. In Adam Ledgeway and Martin Maiden (eds.), The Cambridge Handbook of Romance Linguistics. Cambridge: Cambridge University Press.

Gast, Volker and Johan van der Auwera. 2012. What is 'contact-induced grammaticalization'? Examples from Mayan and Mixe-Zoquean languages. In Björn Wiemer, Bernhard Wälchli and Björn Hansen (eds.), Grammatical Replication and Borrowability in Language Contact, 381-426. Berlin: De Gruyter Mouton.

Haebler, Claus. 1965. Grammatik der albanischen Mundart von Salamis. Wiesbaden: Harrassowitz.

Heine, Bernd. 1994. Areal influence on grammaticalization. In Martin Pütz (ed.), Language Contact and Language Conflict, 55-68. Amsterdam: Benjamins.

Heine, Bernd and Tania Kuteva. 2003. On contact-induced grammaticalization. Studies in Language 27(3): 529-572.

Heine, Bernd and Tania Kuteva. 2005. Language Contact and Grammatical Change. Cambridge: Cambridge University Press. 
Höhn, Georg F.K., Giuseppina Silvestri, and M. Olimpia Squillaci . 2017. Greek and Romance unagreement in Calabria. Journal of Greek Linguistics 17(2): 263-292.

Jakobson, Roman. 1931. Über die phonologischen Sprachbünde. Travaux du cercle linguistique de Prague 4, 234-240.

Jireček, Konstantin. 1901. Die Romanen in den Städten Dalmatiens während des Mittelalters. Erster Theil. Vienna: Carl Gerold's Sohn.

Johanson, Lars. 200o. Turkic indirectives. In Lars Johanson and Bo Utas (eds.), Evidentials: Turkic, Iranian and Neighbouring Languages, 61-87. Berlin: De Gruyter Mouton.

Joseph, Brian D. 1983. The Synchrony and Diachrony of the Balkan Infinitive: A Study in Areal, General, and Historical Linguistics. Cambridge: Cambridge University Press.

Joseph, Brian D. 1992. The Balkan languages. In William Bright (ed.), International Encyclopedia of Linguistics, 153-155. New York: Oxford University Press.

Joseph, Brian D. 2010. Language contact in the Balkans. In Raymond Hickey (ed.), Handbook of Language Contact, 618-633. Oxford: Blackwell.

Kopitar, Jernej. 1829. Albanische, walachische und bulgarische Sprache.Jahrbücher der Literatur 46: 59-106.

Kovačec, August. 1971. Descrierea istroromânei actuale. Bucharest: Editura Academiei Republicii Socialíste România.

Leake, William M. 1814. Researches in Greece. London: John Booth.

Ledgeway, Adam. 2013. Greek disguised as Romance? The case of southern Italy. In

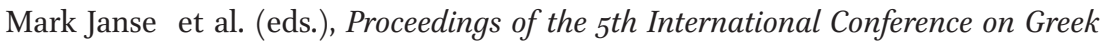
Dialects and Proceedings of the 5th International Conference on Greek Dialects and Linguistic Theory, 184-228. Patras: Laboratory of Modern Greek Dialects, University of Patras.

Ledgeway, Adam. 2017. The Romanian definite article in a comparative Romance perspective. In Adina Dragomirescu, Alexandru Nicolae, Camelia Stan, and Rodica Zafiu (eds.), Sintaxa ca mod de a fi: Omagiu Gabrielei Pană Dindelegan, la aniversare, 231-247. Bucharest: Editura Universităţii din Bucureşti.

Ledgeway, Adam, Norma Schifano, and Giuseppina Silvestri. 2018. Il contatto tra il greco e le varietà romanze nella Calabria meridionale. Lingue Antiche e Moderne 7: $95^{-133 .}$

Lehmann, Christian. 2004. Interlinear morphemic glossing. In Geert E. Booij, Christian Lehmann and Joachim Mugdan (in collaboration with Wolfgang Kesselheim) (eds.), Morphology. An International Handbook on Inflection and Word-Formation, volume 2, 1834-1857. Berlin: Walter De Gruyter.

Lindstedt, Jouko. 200o. Linguistic Balkanization: Contact-induced change by mutual reinforcement. In Dicky Gilbers, John Nerbonne and Jos Schaeken (eds.), Languages in Contact, 231-246. Amsterdam: Rodopi.

Lindstedt, Jouko. 2014. Balkan Slavic and Balkan Romance: From congruence to convergence. In Juliane Besters-Dilger, Cynthia Dermarkar, Stefan Pfänder, and 
Achim Rabus (eds.), Congruence in Contact-Induced Language Change: Language Families, Typological Resemblance, and Perceived Similarity, 168-183. Berlin: De Gruyter.

Loporcaro, Michele. 1995. Recessività sintattica dell'infinito e vitalità morfologica della desinenza infinitivale in alcuni dialetti del Reggino. In Roberto Ajello and Saverio Sani (eds.), Scritti linguistici e filologici in onore di Tristano Bolelli, 331-358. Pisa: Pacini.

Loporcaro, Michele. 2013. Profilo linguistico dei dialetti italiani. 2nd edition. Rome-Bari: Laterza.

Loporcaro, Michele, Francesco Gardani, and Alberto Giudici. 2021. Contact-induced complexification in the gender system of Istro-Romanian. Journal of Language Contact 14(1): 72-126.

Maiden, Martin. 2016. Romanian, Istro-Romanian, Megleno-Romanian, and Aromanian. In Adam Ledgeway and Martin Maiden (eds.), The Oxford Guide to the Romance Languages, 91-125. Oxford: Oxford University Press.

Maiden, Martin. 2018. The Romance Verb: Morphomic Structure and Diachrony. New York: Oxford University Press.

Maiden, Martin. 2020. Dalmatian (Vegliote). In Michele Loporcaro and Francesco Gardani (eds.), The Oxford Encyclopedia of Romance Linguistics. New York: Oxford University Press. doi:10.1093/acrefore/9780199384655.013.726.

Miklosich, Franz. 1861. Die slavischen Elemente im Rumunischen. Vienna: Kaiserlichekönigliche Hof- und Staatsdruckerei.

Reed, Jane M., Boris Kryštufek, and Warren J. Eastwood. 2004. The physical geography of the Balkans and nomenclature of place names. In Huw I. Griffiths, Boris Kryštufek and Jane M. Reed (eds.), Balkan Biodiversity. Pattern and Process in the European Hotspot, 9-22. Dordrecht: Springer.

Rohlfs, Gerhard. 1937. Mundarten und Griechentum des Cilento. Zeitschrift für Romanische Philologie 57(2-4): 421-461.

Rohlfs, Gerhard. 1958. La perdita dell'infinito nelle lingue balcaniche e nell'Italia meridionale. In Omagiu lui Jorgu Jordan: cu prilejul împlinirii a 70 de ani, 733-744. Bucharest: Editura Academiei Republicii Populare Romîne.

Rohlfs, Gerhard. 1972. Studi e ricerche su lingua e dialetti d'Italia. Florence: Sansoni.

Rohlfs, Gerhard. 1977. Grammatica storica dei dialetti italogreci (Calabria, Salento), nnd edition. Munich: C.H. Beck.

Sandfeld, Kristian. 1902. Der Schwund des Infinitivs im Rumänischen und den Balkansprachen. Jahresbericht des Instituts für rumänische Sprache zu Leipzig 9: 75-131.

Sandfeld, Kristian. 1926. Balkanfilologien, en Oversigt over dens Resultater og Problemer. Copenhagen: Luno.

Sandfeld, Kristian. 1930. Linguistique balkanique: Problèmes et résultats. Paris: Champion. 
Schaller, Helmut W. 1975. Die Balkansprachen: Eine Einführung in die Balkanphilologie. Heidelberg: Winter.

Schuchardt, Hugo. 1884. Dem Herrn Franz von Miklosich zum 20. Nov. 1883. SlawoDeutsches und Slawo-Italienisches. Graz: Leuschner and Lubensky.

Seliščev, Afanasij. 1925. Des traits linguistiques communs aux langues balkaniques: Un balkanisme ancien en bulgare. Revue des Études Slaves 5(1): 38-57.

Sims, Andrea D. and Brian D. Joseph. 2019. Morphology versus syntax in the Balkan verbal complex. In Iliyana Krapova and Brian Joseph (eds.), Balkan Syntax and (Universal) Principles of Grammar, 99-15o. Berlin: De Gruyter Mouton.

Skok, Petar. 1915. Pojave vulgarno-latinskoga jezika na natpisima rimske provincije Dalmacije. Zagreb: Knižara Jugoslavenske Akademije Lav. Hav. Hartmana.

Sobolev, Andrej N. 2008. On some Aromanian grammatical patterns in Balkan Slavonic dialects. In Biljana Sikimić and Tijana Ašić (eds.), The Romance Balkans: Collection of Papers Presented at the International Conference The Romance Balkans, 4-6 November 2006, 113-121. Belgrade: Serbian Academy of Sciences and Arts, Institute for Balkan Studies.

Squillaci, Maria O. 2017. When Greek Meets Romance: A Morphosyntactic Investigation of Language Contact in Aspromonte. Cambridge: University of Cambridge. PhD dissertation.

Stolz, Thomas. 2002. No Sprachbund beyond this line! On the age-old discussion of how to define a linguistic area. In Paolo Ramat and Thomas Stolz (eds.), Mediterranean Languages: Papers from the MEDTYP Workshop, Tirrenia, June 20oo, 259-281. Bochum: Brockmeyer.

Stolz, Thomas. 2006. All or nothing. In Yaron Matras, April McMahon and Nigel Vincent (eds.), Linguistic Areas: Convergence in Historical and Typological Perspective, $3^{2-} 5^{\circ}$. New York: Palgrave Macmillan.

Swadesh, Morris. 1951. Diffusional cumulation and archaic residue as historical explanations. Southern Journal of Anthropology 7(1): 1-21.

Thomason, Sarah G. 2001. Language Contact: An Introduction. Edinburgh and Washington, DC: Edinburgh University Press and Georgetown University Press.

Toman, Jindřich. 1995. The Magic of a Common Language: Jacobson, Mathesius, Trubetzkoy, and the Prague Linguistic Circle. Cambridge, Mass.: The mit Press.

Tomić, Olga M. 20o6. Balkan Sprachbund Morpho-Syntactic Features. Dordrecht: Springer.

Tosco, Mauro. 200o. Is there an "Ethiopian language area"? Anthropological Linguistics $42(3): 329-365$.

Trubetzkoy, Nicolai S. 1923. Vavilonskaja bashnja i smeshenie jazykov. Evrazijskij vremennik 3: 107-124.

Trubetzkoy, Nicolai S. 1928. Proposition 16. In Actes du Premier Congrès International de Linguistes: À La Haye, du $10-15$ avril 1928, 17-18. Leiden: A.W. Sijthoff. 
Tsitsipis, Lukas D. 1998. A Linguistic Anthropology of Praxis and Language Shift: Arvanitika (Albanian) and Greek in Contact. Oxford: Clarendon Press.

Vezenkov, Alexander. 2017. Entangled geographies of the Balkans: The boundaries of the region and the limits of the discipline. In Roumen Dontchev Daskalov, Diana Mishkova, Tchavdar Marinov, and Alexander Vezenko (eds.), Entangled Histories of the Balkans - Volume 4: Concepts, Approaches, and (Self-)Representations, 115-256. Leiden: Brill.

Zegrean, Iulia-Georgiana. 2012. Balkan Romance: Aspects on the Syntax of Istro-Romanian. Venice: Università Ca' Foscari Venezia. PhD dissertation. 